\title{
Interview with Professor Chaitanya Mishra
}

- Madhusudan Subedi \& Man Bahadur Khattri

DOI: https://doi.org/10.3126/dsaj.v15i01.41931

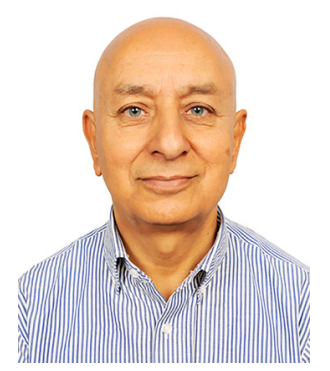

Professor Chaitanya Mishra teaches Sociology to MPhil/PhD students at Tribhuvan University (TU), Nepal. His research focuses on macrosociology, politics, social change, and social stratification. He is an author/co-author, and co-editor of 10 books and about 250 articles. He believes that all sciences should contribute to public education, and frequently contributes to public debates through the media. He started his career in 1978 as a researcher at the Institute of Nepal and Asian Studies, TU. In 1981, he was appointed the founder Chair of the Central Department of Sociology/Anthropology, TU. He has written on the development of sociological knowledge in Nepal, its disciplinary growth, empirical and theoretical orientations, as well as strategies that could be adopted to meet contemporary disciplinary challenges. His contributions have led to theoretical debates on the issues of development or underdevelopment of Nepali society as well as the nature and causes of economic and political divisions and alternative trajectory of change. Professor Mishra served as a member of Nepal's National Planning Commission (1994-95), founding president of Nepal Sociological Association (2017-18), Fulbright Visiting Professor and Hubert Humphrey Professor of Sociology at Macalester College (2015-16), and founding Executive Chair of the Policy Research Institute (2018-19) of the Government of Nepal.

\section{Question 1: Could you describe your personal and familial background?}

I was born in November 1951 on the immediate outskirts of Kathmandu when this city was merely a town. Our locality had a distinct feel of a village with had no motorable road. By the time of my late childhood, I had become familiar with almost all of the households in and around the settlement.

I was brought up in a nuclear family, except for the initial four years of my life. I grew up with a younger brother and a younger sister. My family network was fairly large. We were Bahun by caste. We owned a home and a small plot of dry and low productivity farm. Both of my parents were clerical government workers. My mother belonged to a tiny group of first-generation non-housewife office workers. We were far from well off in terms of income. On the other hand, many of our neighbors, friends and relatives were in bad condition we were. Our economic condition improved during my mid-teens.

I married when I was almost 36. My wife, Mira teaches Gender Studies. We have now been happily married for 34 years. We have one daughter who now works as a management consultant.

By my late childhood, I could discern that social life had begun to change at a fairly rapid pace. The salience of caste identity was under erosion, except in relation to marital selection. A road was coming to our village. "English education," with its disparate yet massive cultural, political, and tradition and "indigeneity"-eroding and modernity-inserting significance, had become the norm. The clothes people wore were changing. "Modern" young men strutted in "Western" pants and some girls could be seen with similarly "modern" clothes. Newfangled political terms and frames were springing up. There were speeches by political leaders in and around our neighborhood. Some households were setting up "basket 
shops" (nangle pasal) and other tiny shops and reneging on the "immorality" of selling things and extracting a profit. Libraries and civil associations were emerging. My father was the general-secretary of one such "progressive" association. Even the unrelenting and "natural" regulations of caste and gender seemed to sway a bit. By my early teens I could see that my own father had had his own questions in matters of caste and even gender. Most importantly, the new, while sometimes controversial, was legitimate and on the ascendant and valued. There was a romance attached to it. It seemed like the "modern" will be routinized and dominate the future.

Question 2: What or who influenced you to opt for Sociology? Did you happen to imagine yourself as a sociologist during your college days?

Steve Jobs once said that it was possible to comprehend the sequence of life only backwards, from the present to the past, not the other way around. His point, of course, applies as much to an individual as for the discipline of History, which continues to struggle over whether it is possible to reconstruct the past "as it really was" or whether history can be read only backwards through the prism of the present. As powerful as Jobs' assessment is, I personally have my doubts even there. There are so many dots - layered dots, squiggly lines, spirals and so forth, in the passage of a life that it is very difficult to trace current features of human life to a specific past. This, of course, takes us to notions of proof, falsification and the entire problem of causality. In any case, "visible" or connectible data points that led me to Sociology appeared rather late in my life.

During my high school, I was a "pass" student, except in the languages. Geography, I must add, also seems to have been an exception. I enjoyed learning geography beginning when I was 7-8 years old. This enjoyment flowed from my access to a thin yet amazingly informative volume of Oxford World Atlas that belonged to my father. That was really the only book I wished to learn from out of my own volition. That also made me hungrier for information and knowledge about the physical, political, cultural, etc. features of the world that lay beyond my immediate confines. The Atlas, published in India, was detailed on India even as it had only a few pages on the rest of the world. But the message was clear: What was available in that volume on India would be available in other atlases. I only needed to look them up someday.

As far as my schooling went, I did not know much and was unworried about not securing the higher grades. I sometimes wonder if the fact that I passed the $10^{\text {th }}$ grade (in the remedial School Leaving Certificate examinations) - the highest grade in high schools at the time - when I had barely touched my teens could have been a factor there. Maybe I should note here that my parents' overwhelming priority was for me to complete my high school and land a job immediately thereafter. That was, in fact, the norm among almost all parents I knew. I did not go to school to learn; I was goaded into the school and pushed to pass the tests. That was also normal among the parents I knew. Actually, only a few of my school friends passed high school. With hindsight, it was a wide expanse of mediocrity of learning and aspiration that I inhabited.

This, however, began to change after I enrolled in the College of Education, Tribhuvan University, Kathmandu. Foremost, the rather large, spread out and sunny library with gleaming books and furniture and a few students and teachers poring over books just drew me in. It kind of fertilized in me the desire to know. Here was a place that really invited me. Further, I had quite a few good teachers who helped me along. In addition, the College of Education introduced me not only to Education as such but to a broad range of fields, e.g., Psychology and Educational Psychology, Child Development, English and Nepali Languages and Literatures, Economics, Political Science, Geography, and so on. I regularly participated in class discussion. I did quite well in the final Intermediate and Bachelor's exams. For reasons that can be long to describe here, I also appeared for the Bachelor of Arts final exams and did well there as well. In the meantime, I had also read through several South Asian epics like the Ramayana and Mahabharata, Buddha and Gandhi as well as a lot of spy novels both in Hindi and English and, almost inevitably, watched hundreds of Bollywood and a few Hollywood films. I was becoming familiar with conditions in other countries and societies.

In the meantime, I was undergoing a profound personal churning beginning my late childhood, which intensified during my early and middle teens. Initially, this mainly had to do with the caste system and my personal caste identity. Was the system and identity just after all? Was the system and identity in keeping with what I was learning in my school and college and in life? Were the caste practices I performed, e.g., maintaining a top-knot of hair, wearing a sacred thread, maintaining commensality, either justified or useful? Or did these norms and practices lead to disrespect and inhumanity such as when I showed an ambivalence about commensal practices with my Damai Dalit neighbor who was regarded as "untouchable," or contradict, harm and lead to widespread violence, a la 1947 Bengal and Punjab? Questioning caste system and practices led, within a couple of years, to further questions regarding faith and divinity. The questions were mentally, intellectually and emotionally searing. It was a roller coaster that could not be fully shared with others either. In consequence, it was also socially tearing, notwithstanding my belief that my path was the right one. Further, like many of my friends, I imbibed harshly negative views about colonialism, monarchy, and global inequality.

I had become certain that divinity was both an inauthentic and unsafe foundation for the rise of life and society. But I did not take the next plunge and then go on to ask about what could be the authentic and safe 
foundation(s) for the flowering of life and society. Perhaps, I was satisfied with one answer at a time.

While these experiences did not directly lead me to Sociology as such, it appears to me now, connecting backwards, that it did lead me to a particular "brand" of Sociology. That brand was one that emphasized the macro, structural, non-reductionist - a la Durkheim, historical, theoretical, trans-disciplinary, and so on.

I came across the term "Sociology" for the first time in early 1969. A cousin brother of mine had asked me to go through a newspaper announcement that day. The call there was to apply for a scholarship to study Masters in Sociology at an Indian University. The study there would be funded by the Colombo Plan and the government of India. I subsequently applied, and was fortunate that I was selected.

Within a period of three months, I not only learned that there was a discipline called Sociology but was also going to pursue my graduate study in that subject. Life plays amazing tricks. As I noted, I had acquired some reflexivity as well as a critical edge in matters social. But without that newspaper announcement and final selection, I would not have become a sociologist. Not by any stretch of imagination.

\section{Question 3: At Nagpur University and the University of Florida when you were there, what theories and research trends were more common? What exciting experience did you get as a student of sociology? What were the similarities and differences of the teaching- learning environments in the two universities?}

My experience in the two universities was quite different. In Nagpur, I was, for the first year and in terms of academics, fairly insecure. Because of bureaucratic bungling, I reached there late, almost six weeks after the classes had begun. On the other hand, I thought that I carried the responsibility, as a scholarship holder, to build a "good-student" reputation. I enjoyed reading books in the new discipline I had opted for. The library, once again, was a huge help. In addition, my scholarship allowed me a facility to buy personal books. I cannot say I read through the long hours of the night but I skimmed through chapters and books with speed. The overriding intention was to do well in the first-year exams and move on to the next. I succeeded at that. The second year was spent, once again, with a lot of books but with far less insecurity.

In Nagpur, all of the courses were of an introductory nature. One course each on classical and modern theory, and one course each on research methods, social psychology, Indian society, social change, industrial sociology, and organizational sociology totaling eight papers in two years. There were no course choices, no classroom discussion, no writing assignment and no research "practical". Due to the paucity of teachers, thesis writing was not offered either. Most of my classmates were motivated not to study or to excel but to pass the exams.
Like most universities in India at the time and even now, academic program in Sociology at Nagpur was not designed to produce sharp, state-of-the-art practitioners of Sociology. It was, instead, a mill that largely produced middling graduate students who would attend classes while at the same time carrying out or applying for fulltime jobs in a host of fields. Except in the case of a couple of students, it was a Master's certificate that was valued. And, in this case, it just happened to be in Sociology.

I was on the way to making a shattering learning about myself when I came back to Kathmandu. I had excelled in grades in Nagpur. But I realized, during the course of my job search, that my excellence was limited to books and in rather abstract and windy concepts and frameworks. I had, by a wide margin, failed to learn how to carry out a concrete social analysis on my own. Sociology, for me, had become what the old guys told us in books rather than what was happening around myself and people I cared. At best, there was a very thin weaving together between the two. In addition, whenever such weaves did take place the old guys would win hands down. To add, I did not know much about Nepal either. Beyond the ambit of what the books told me, I was not much different from a layperson. This realization viscerally pained me. I promised myself that I walk down another path in the future.

After remaining unemployed for close to eight months and working as a radio and print journalist for another 16 months, a new opportunity knocked in. I applied to a Fulbright-Hays scholarship for graduate study in the USA. It was another stroke of luck that I was one among the four selected that year. I then started my graduate work at the University of Florida.

Following the realization that high test grades had not served me well, my interest in that direction had cooled down by quite a bit. (I try to make myself believe that my measly coursework GPA of 3.3 in Florida had something to do with this "lack of interest".) On the other hand, in Florida, I began to link books to ongoing social life - my life, the lives of people I knew, of people in the US and the world. That made the books come alive. I also learned to make a reverse connection - not from books to life but also from life to books. This has been an enjoyable and ongoing pursuit ever since.

I had also made up my mind that I was in the US and at the University of Florida not to study "just" Sociology but to learn as much as I could about the US and about the world as a whole. I believed that such an opportunity would be unlikely to recur in the future. At the University of Florida, there were many courses offered. I took courses upon courses - graduate and undergraduate - and made much use of the library. I did not take time off during the summers either. I was always in school through my 4.5 years there.

The university had acquired an edge in the study of the family and was acquiring one in gerontology and the sociology of health. However, those programs failed to 
draw me in. Instead, I enrolled in all of the metatheory and theory courses as well as a sizable number of courses on methodology on offer. I read several texts on the philosophy of science on my own. I also took courses offered about race, poverty in America, Latin America, and economic development. There was not a single course on Marxism, at least not in my department. I read one thin text by Karl Marx and Frederick Engels on German Ideology as part of a course on social inequality and epistemology. I read a couple more of Marx's writings, materials on philosophy, religion, Frantz Fanon and several others on the construction of race and racial oppression and inequality. Finally, I also read a considerable amount on the construction of gender and gender inequality. One upshot of all this was that my thesis examined the relation between occupational inequality on the one hand and race and gender in the US on the other.

Question 4: Your writings utilize the capitalist worldsystems framework and the interdependence of the world today. How did you take up this theoretical idea?

As I reflect back, I think it was a confluence of five processes. Of course, at the time, I mistakenly considered the five to be disparate trains of thought. The first was my affinity with theory - the general, the macro. I was, shall I say for now, and with hindsight, had a metatheoretical pot that was looking for a substantive filler. I had, in a manner of speaking, a theoretical bent sans substance. The second was my preoccupation not with Marxism as such but with Marx and writers of that genre. Marx gave me a powerful and totalizing gaze. The third was the history and structure of colonialism and imperialism, the dependency theory being developed in Latin America as well as the nature of global inequality and, closer to home, the nature of political-economic relations between Nepal and India. The fourth was my enthusiasm for history and the historical process. Much of the last two were acquired when my student days were over and after I had come back to Nepal. The concern with history of Nepal, in particular, took up much of my time. I was fortunate, however, that my initial appointment at the Tribhuvan University was at the Centre for Nepal and Asian Studies where I had a number of prominent historians as colleagues. Among them were Prayag Raj Sharma, Father Ludwig Stiller, Dhanavajra Bajracharya and Gyan Mani Nepal. In addition, I read a lot on Marxism, courtesy of the Progress Publishers which massively subsidized Marxist and Soviet books. Finally, I read considerable literature on world history, courtesy of the American and British libraries in Kathmandu. In fact, I was so taken in with these fields that I published little for the initial five years of my employment. This includes my time as the head of the Department of Sociology as well as the year I spent, in a substantive sense, taking a fulltime load at the department. Finally, I have also wondered if my passing knowledge of the expansive, complex, multi-vocal nature of the "Hindu" cosmology contributed to my fascination with the macro. I also recall that I was fascinated during my early college years when I read Fred Hoyle's The Nature of the Universe that took me, once again to the infiniteness of the universe and its history.

It was at this juncture that I came across a book, Dynamics of Global Crisis by Samir Amin, Giovanni Arrighi, Andre Gunder Frank and Immanuel Wallerstein. The book was published in 1982 but I got to read it three years later in 1985. It was a seminal book that neatly and powerfully brought together what had remained relatively distinct frameworks and mutually untied strands of data points for me. The book clicked exceptionally well with me. The upshot, first, was a revelatory validation of what I had been thinking at both concrete and subliminal levels. Second, it tied up what had remained, for me, distinctive data points as well as frameworks. Third, it also hinted at how I should proceed to do sociology ahead. I have not been partisan to Samir Amin's political thinking since. On the other hand, I have followed Wallerstein rather closely since and also remained an admirer of the relentless iconoclasm of Frank.

In this vein, my priority both in teaching and writing has been to locate a specific people, country, economy, polity, etc., within a specific yet encompassing worldhistorical whole or at least a spatial-historical whole at a less encompassing level of aggregation. While I tend to prioritize the macro, I have consistently attempted to link the nature of relations between a micro and an encompassing macro. The nature of relations between agency and structure can be considered a subset of the macro-macro linkage.

In addition, I tend to prioritize macro - both history and structure - over micro and agency because I think that is what Sociology calls for. Disciplines today are developing as much more as specific stances taken to gaze at the world rather than as specific subject matters of interest. I think it is important to exploit this potential of a disciplinary stance, which is the sociological stance in my case.

I noted earlier that I was moving away from faith, religion, and divinity based accounts and explanations of social forms and relations. Somewhat later, and gradually, I added up what I considered to be a Sociology-unfriendly "negative list" made up of naturalization, psychologization, physiologization and biologization. Naturalization, because it kills off the spirit of problematization and inquiry, has long been a bane of all sciences, including Sociology. In addition, it has been clear that individuals, and changes in their social features have increasingly and illegitimately been invalidly psychologized and physiologized or biologized. Physiology and psychology have increasingly tended to provide what I consider illegitimate substitutes of Sociology and knowledge. For example, the brain, which is certainly a physiological wonder, has been invoked ad nauseam by almost all of the biggest minds of the last two generations of scientists to account for a variety of personal and social attributes notwithstanding 
the massive and growing evidence on neuroplasticity as well as the mind-body-society connection. It is notable that most of those who acknowledge the significance of the mind-body interaction fail to find a space there for society. Psychobabbles, both popular and high-brow, in turn, leave little space either for individual and social differences or for structure and history. Despite the dense and sharp link of mental and emotional makeup with the nature of social relations and institutions, psychiatry has largely been individualized, psychologized, medicalized and pharmaceuticalized.

Some sociologists and social scientists have occasionally pointed this out and suggested that the insertion of the social domain is called for. But the voice, I think, has remained few and far between, inconsistent and feeble. It has not been well worked out. It has not come close to challenging the naturalization and silo-ization of physical and life sciences, medicine and technology in particular. It is as if physical and life sciences, medicine and technology stood apart from the world and society they were conceived of and practiced within. In addition, it is as if these domains had a life of their own unlinked with and unattached - un-facilitated and unencumbered by the social domain. It is clear, on the other hand, that while the hegemony of the three domains is overpowering, its validity and legitimacy are not.

In addition, I have long felt that the scope and depth of the social domain to shape thinking about the physical, chemical, bio-physiological, psychological, and technological. domains have been severely underexplored. While some anthropologists have taken important steps along this direction, sociologists, in particular, have remained the least engaged and daring. Hopefully, climate change, increasingly frequent forest fires and floods, epidemics, famines, and wars will play the same role that economic and social transformation did for Marx, Weber and Durkheim during the latter half of the $19^{\text {th }}$ century and give sociologists today the insight and persistence required in order to herald a new social science and sociology that illuminates physical, chemical, biophysiological and similar other processes.

Let me pursue this line of reasoning a bit further. The maxim that "we do not see the world as it really is but as we are," which has been attributed to a large number of intellectuals as well as scriptures, e.g. Immanuel Kant, David Hume, Anais Nin, the Talmud and others, goes quite some way in underlining the significance of an expansive re-visioning of the scope of Sociology. Einstein could be understood to have hinted as much when he told us "The world as we see it is the world only as we see it. Others may see it differently." Perhaps it is in this line that Sociology continues to be practiced under several metatheoretical stances, each of which produces a distinctive image of society.

There has to be one additional opening. It is time that the notion of the "social" be defined in a much more encompassing manner such that it includes specific aspects of psychological. physical and life sciences and the technological world within it. It has now become necessary to tread beyond the old, self-imposed and normalized confines that have also been shaped under the hegemonic lens of the psychological, physical and life sciences. It will certainly not come easy. But the confining traditional vision has severely limited and distorted the intellectual horizon of the social sciences.

Sociology, for example, has contributed little to the study of bio-physiology, climate and climate change, epidemics and pandemics, disasters, expanded and ceaseless reproduction of a variety of risks - including of expanding nuclear arsenal and its delivery, drone and other AI militarization, etc. Sociology has not yet ventured to study intimate entities such as the human body, birth, and death, all of which are very largely and invalidly merely seen as physiological entities and life events.

Let me bring in the human brain here once again. The human brain has long been a focus of physiological and neurological investigation. The number of neurologists, institutions that are involved in brain research, the scale of research and funding, number of neurological journals and articles. have recently skyrocketed. It is constantly in the news and catches a huge amount of public attention. Yet, sociologists seem to have reconciled to the idea that the brain is little more than a physiological "thing" -and despite the burgeoning accounts of neuroplasticity. In this vision, the brain legitimately belongs to the life sciences and there is nothing to benefit there from a sociological gaze. On the other hand, it is increasingly clear that the brain, in particular the "software" and the "data" that are imprinted upon and run through it is socially conditioned and reshaped. Significantly, it, has become increasingly clear that the physiology of the brain is itself socially shaped. The ontological, epistemological, moral as well as all other imprints that the brain is etched with, and how that, in turn, reshapes the physiology and working of the brain, has completely evaded the sociological gaze. More significantly perhaps, human evolution has very often been studied without much intervention from Sociology. All in all, Sociology, at best, has made attempts at researching the social outcomes of such physical, bio-physiological, psychological states and processes of being. The discipline very often has not, on the other hand, dared to visualize itself as one of the causal or antecedent factors leading to specific physical, bio-physiological and psychological attributes and processes.

In addition to that described above, a new sociological visioning will enable scientists to describe and explain how the physical, biological, psychological, technological on one hand and social domains on the other together produce and re-shape one another. This will immensely enrich both the social as well as other sciences and technologies. The upshot will be the reconfiguration of a more encompassing as well as more valid and reliable knowledge. 
It is in such instances that I cannot fail to recall the brilliance of Emile Durkheim, who cut through the debris and insisted both on non-reductionism and social explanation as the hallmark of Sociology. Marx, Weber and a few other sociologists did the same, even though Weber sometimes found himself torn between the relative primacy of the society and the individual. While there are many sociologists I can recall, in these instances, it is Durkheim in particular who empowers and liberates me as a sociologist. I have always, as a sociologist, felt that the Durkheimian ideas had not been pursued to the fullest.

My own little slice of Sociology, in consequence, grew up as a denial of divinization and naturalization and as a resistance to expansive and excessive physiologization, psychologization, etc. Psychology, bio-physiology, and technology are fundamentally important in social life. But the reverse is equally true: psychology and physiology or biology, and technology are, in part, socially constructed. Hence my claim, published in 2009 in this journal that Sociology is everywhere. Thus, farm soil and drinking water, birth and death, body and hair, sanity and insanity, pen and chair, mind and consciousness, science and technology, and computer, cell phone and television, climate and weather, knowledge and disciplines, and so on are, in part, socially constructed.

Now I do not at all imply that sociologists should study the physiology of the human brain. However, if the human brain is socially imprinted, sociologists must study the nature of the imprints, how the imprints interact with one another and with the physiology of the brain. This task is perhaps best performed, at least during the initial period, in collaboration with other brain scientists.

Nor do I imply that the sociologists must focus on the human brain as such. Maybe that the human brain can be transformed into a more "sociological" category such as the mind, thinking, and leading. Maybe that the action metatheory of Max Weber, Talcott Parsons, etc., could be amended and recast to include both the imprints of social action on human brain and the tendency of the human brain to lead to specific human action. Similarly, we could think of George Herbert Mead's category of the human mind as a sociological category that could possibly be recast for the present purpose. Sociology, of course, has also been closely implicated in the description, explanation and remedy of mental illness. These are merely pointers that could be followed up and extended much wider and deeper following a re-visioning of Sociology.

It is essential to visualize specific social relations and institutions as causal factors that lead to "nonsocial" outcomes. For example, we often surmise the consequences of a specific technological device upon social life. But we rarely, if ever, wonder about the nature of the social form that led to the device in the first place. It gradually seeped upon me that it was important for sociologists to gaze at social forms as causing, in part, all of the "things" we live with. As we have seen, it is invalid to think about the climate as something "natural;" it is, instead, a social product. So is, I think, the SARS-CoV-2. In essence, there is nothing that is not social, that is not caused by the structures of social relations as it may also be caused by factors that could be said to be one step removed from the social.

I must add that I hold this "every discipline everywhere theory" to be true for all disciplines. Surely, you can "find" physics and chemistry in operation everywhere. I suppose the same could be claimed for biology - except perhaps for the period in the universe where there were no living beings. But Sociology has not, to my knowledge - and I may well be wrong here, not powerfully made such a claim yet. Regardless, I hold it as a truism that Sociology, as is the case for all other social sciences - remain "in operation" everywhere, in all "things" and across all historical periods inhabited by human beings. We fathom Sociology not only as a substantive body of knowledge but also - and increasingly so - as a specific stance to visualize the world we have lived and acted in.

Going beyond Sociology and other social sciences, the vision of "every discipline everywhere and always" can not only enrich physical, biological and psychological sciences but also lies at the heart of interdisciplinary and transdisciplinary pursuits. Disciplines can allow us vantage points that are sharp and piercing. Most disciplines as we know them today were developed and institutionalized in order to capture partial realities in the first place. We cannot let that go. Because every discipline can be implicated to gaze at everything everywhere and across historical periods, all disciplines must be linked together in order to approximate the whole of anything. We should utilize disciplines to catch the world we inhabit in as sharp relief as we can and simultaneously engage in interdisciplinary engagement in order to arrive at a fuller view.

Question 5: Methodologically, you highlight the historical-comparative perspective. What made you favor this perspective? What are the advantages of this methodology for analyzing Nepali society?

There are two well-crystallized modes of inquiry that help us investigate macrosociology and the macro-micro link, and the world-systems and the historical-comparative approaches. These approaches center stage the significance of the study of the large scale and the long run. This by no means implies that micro studies that employ symbolic interaction, ethnomethodology and other interpretative methods as companion modes of investigation are not significant or relevant to Sociology. Both of these methods are also evolving.

These two modes of the investigation were developed rather independently. The historical-comparative method has been with us for long in all of the social sciences. Social sciences as we know it today were born in order to wonder and gaze at a rapidly changing, diverse and conflict-ridden societies. This gaze became particularly encompassing 
and sharp during and following the last and Europe-led capitalism and industrial revolution that took hold between the $16^{\text {th }}$ and $18^{\text {th }}$ centuries. The scale and speed of this mighty revolution implicated and reverberated through all aspects of life and society and, as we know now, the earthly ecosystem as a whole. It fundamentally transformed social relations and has been doing so in a pervasive and perennial fashion ever since. Essentially, comparative historical sociology sought to compare a few specific states and societies as to how they fared through the ups and downs of this massive transformation in comparison to some other states and societies. Comte, Marx, Weber, Durkheim and other precursors of Sociology all were predisposed in order to answer this large-scale transformation and what that implied for social life. The gaze, as we know, also became important to address the changes and problems unleashed by these mighty historical forces. This vision, after a longish hiatus, was refined by Barrington Moore in his Social Origins of Dictatorship and Democracy. Both institutional platforms and the intellectual power of the comparative historical mode of inquiry has since rapidly grown.

The world-systems approach, in turn, was gradually put together beginning in the early 1960s. It prioritizes and begins with the assumption that human society today lives within a single integrated modern capitalist world-system. To be sure, the world is not even and equal. Wrinkles, unevenness and inequality are inalienable parts and parcel of the capitalist order. Such wrinkles are simultaneously spatial and historical.

It should be noted that a structure is not a singular, mammoth, fully integrated, fixed and unchanging entity. Nor is history a perennial and ever-continuous flow. Structures are oftentimes a unity that is partially internally broken, differentiated and rife with contradictions. In addition, a structure is always in a flow, and it changes over time. In other words, history is a process that bends, moves backward and forward, pours forth, trickles and moves in a near-still manner. This unceasing structural-historical flow generates a series of contradictions and conflicts that are more or less resolved in the due course of time. But the resolution, in the next stretch of history, itself generates other contradictions that eventually break down the world capitalist order as a whole. The flow and ebb of capitalism are also part of the order. Ebbs and flows in history also generate contradictions that require repeated resolutions which end up breaking the order down yet again.

On the other hand, the end of this specific round of the world-capitalist system, unlike that enunciated in the Soviet and old Maoist dogma, by no means ushers in the socialism that two dogmas teleologically predict. I have elsewhere argued, in part as a critique of Vladimir Lenin, that even as the demise of capitalism is certain, it is not going to happen right away. Lenin, of course, deluded us in 1917 that capitalism was hurtling to its demise and that it was time for us to push it down further. The implication of the Leninist position, of course, was huge inasmuch as the Communist Party of the Soviet Union (CPSU) became the official interpreter of Marx and Engels as well as of Socialism as a whole. And the CPSU for long, i.e. at least until Mao Zedong, became the mother party of communist parties across the world.

Given that the capitalist world system is alive today, my argument went, the dogma that a sustained Maoist transition could be implemented in Nepal was no more than a delusion. The historical course that China has taken during the last 45 years, the advent and demise of Eurocommunism as well as the demise or transformation of communist parties elsewhere in the world is more than enough both to falsify this teleology is also to kill the prospects of communism and Maoism in Nepal during this particular phase of world, regional and national history.

In addition, the end of the capitalist world-system does not necessarily prepare the grounds for socialism in Nepal or elsewhere. It may lead, for some time, to several geographically or politically truncated regional capitalist systems or to national capitalism. In either of the cases, we shall be living under capitalism, although a different one than we are in now. Or, the end of capitalism may lead to faith dominant or ethnicity dominant states that lie far from the socialism of the two dogmas. The end of the world capitalist system may also lead to a prolonged period of anarchy. Indeed, under conditions of war and seclusion, it is not impossible for a far-off region to usher in a new era of feudalism. What is certain is that national, ethnic, and ideological borders and boundaries will be largely redrawn and social belonging will go through a prolonged turmoil. The foundations of social relations beyond the immediate family may become massively uncertain and brittle.

Now, even as the historical-comparative and the world-systems metatheories did historically develop as two distinct approaches, I thought it was wiser to coalesce the two together. In particular, I have been convinced that it would be far more illuminating to nest the historicalcomparative approach within the world-systems approach. It is good to compare a few specific countries or societies but one should not lose sight of the fact that countries today are located within a single integrated historical and structural whole. Surely, the capitalist world now shows a fair amount of wear and tear. Symptomatically, the USA, in particular, is threatening to stand apart from much of the rest. But it is to be seen whether the wear and tear can mend itself or tatters further. Whether the nesting of the two approaches is valid is not a logical but historical question.

For both the comparative historical method and the world-systems approach - the nature of relations among the three hierarchilcal categories that make up the ongoing world system, i.e. the core, semi-periphery and periphery as well as the ebb and flow of the world capitalist dynamic, comparison - both historical and spatial - is germane to 
social understanding. There can be no learning whatsoever without comparison, whether implicit or explicit. A child learns by comparing among those who care, temperatures - i.e., warm and cold, toys and furniture, cats and dogs, etc. All knowledge, whether explicitly or not, is comparative arrived at knowledge. Nepal itself has no special affinity with the historical-comparative vantage point. The method is a tool for acquiring a valid knowledge of and in Nepal as also of all other places and historical periods.

We can now come to the Nepal question. Nepal is part and parcel of a single integrated world system. It is utterly foolish now to seek to set Nepal apart from the rest of the world and humanity. That stance will neither lead to a valid comprehension of any particular feature of Nepal or Nepal as a whole. Nor will it lead to workable policy priorities. Most Nepalis and many academics in Nepal have an enormously misplaced notion that Nepal is somehow very different from all of the rest. This attribution of uniqueness, of course, is not unique to Nepal. An outcome principally of patriotism, in all countries share in this warm and often false pretense.

A mutually collapsed world-systems and comparativehistorical epistemic frames, by appropriately locating Nepal within the global, regional and internal orders, could potentially have enabled intellectuals, politicians and policy makers to sketch the "external" positioning and "internal" make up of Nepal better. This, in turn, would have led to both more valid knowledge systems about Nepal as well as better politics and policies. I would think that would have been helpful in identifying and implementing economic as well as welfare opportunities better and in a timely fashion.

As a more concrete example, I think a world-scale and historical-comparative thinking could have promoted both intellectual and popular examination of the Maoist armed uprising. Such an approach could have isolated historical-spatial as well as political economic - states and societies today, if any, where Maoism could be sustainably implemented and also pay off. Such approach could potentially also have predicted that the Maoist political party would, in the true Leninist fashion, do all it could to block the process of formulation of a constitution even after agreeing to and implementing an election to a constitutional assembly. Unless, of course, the assembly and the constitution upheld the kernel of the Maoist strategy, that of one-party rule. Such encompassing thinking could also have gone some way to fully comprehend and educate the overarching design of the government in India, which willfully allowed the top Maoist leaders to operate from Delhi. And this, despite the fact that India was the first country to designate the Maoists as a terrorist entity.

To take another concrete example, I think the comparative historical approach could potentially have provided a wider public education as well as an impetus to successive governments of Nepal to do all they could to open up and utilize trade and transit outlets from China. From the point of view of sovereignty, this has remained an existential question for Nepal for a long, particularly following the 1951 Nepal-India treaty that ties Nepal to India in matters of defense and much else. I would imagine the first opportune time for this could necessarily have arrived in the early 1970s following the signing of the IndoSoviet defense treaty and US-Chinese rapprochement. Of course, there were other opportune periods for such opening as well. The point is not that a gaze under such approach would have led to such an outcome but that it could have both up-scaled public education and prodded the various states and governments of Nepal in this direction. Such opening, of course, would have enabled Nepal to avoid or reduce the physical, economic and psychological damage due to the blockade India enforced in 2015 and several times previously.

Similarly, the ongoing simmering debate on whether Nepal should realign itself with Hinduism and cancel its already watered down secularist position in the constitution can find much useful insights from the experience of other countries and cultures. It can also learn much and derive lessons from a perusal of Nepal's own history on whether a hardline undertaking on faith is compatible with the goals and futures Nepal wishes to attain. Such inquiry, among others, will certainly lead to a powerfully negative answer on the link between faith and democracy. Else, it can reach the same conclusion through a perusal of such a link in India today.

Now, it is the case that the comparative historical method was partial to the qualitative approach. The rather small number of cases (often labelled Small-N), which are often states and societies, that it studied was an outcome of its reliance upon the qualitative method. Comparable across-state and across-society quantitative data were not available at least until the 1980s. Very largescale quantitative information, the Big Data, of course, is a mostly post-2000 invention. Now that such data are available, there is less reason for the comparativehistorical method to cater to just a few cases at any one time. Nonetheless, while much of the required quantitative data may be available across states and societies data for the present, the paucity of long-run historical data will continue to limit the comparative historical method from an exclusive reliance on large data sets. Nonetheless, quantitative data has come into use in comparativehistorical studies and this trend is likely to catch steam. The utility of the comparative historical approach lies in asking big questions and answering them better than any other methods. This has become particularly important since most intellectual tendencies, political-economic exigencies as well as methods are geared to methods and techniques that overvalue and restrict themselves to the present and ones that seek immediate answers to short run questions.

Having dwelt on the comparative historical and world systems approaches at length, I do not at all wish to claim that any other approach is invalid. I see more pluses in 
these approaches than the rest. I appreciate many other approaches as well. The point is to bring forward valid and reliable, large scale, insightful and sharp slices of knowledge that link up the macro and micro as often as possible.

\section{Question 6: Nepal has lurched forward into transitioning from a unitary state to a federalization. We have remained watchful and optimistic on the transition to federalism thus far. Yet, we sense an increasing ambiguity as well. While this is understandable in the initial-stage implementation of a large-scale program such as federalization, a more effective collaboration and coordination among the three tiers of government appears wanting. How do you see it?}

I cannot answer this question with the degree of refinement you propose because I lack adequate information. My answer, in consequence, will be rather "thick".

For Nepal today, I favor a federal state than a unitary one. However, in contrast to secularism, which also appears to be under some cloud, I am not, at the level of principle, inalienably wedded to federalism. We see, in the world today, unitary systems effectively delivering not only services but also serving as a platform for political organization and belonging. France, for example, or Denmark or Bangladesh for that matter. None of the preceding three is a federal set up, but the former two possess well devolved political and administrative systems. There are many more examples where local governments provide all of the three "services" I alluded to. From another angle, the Ethiopian tragedy today is a direct outcome of a sharply ethnically-based federal structure. I make a particular note of the Ethiopian example because not too long ago there were powerful political forces who regarded the model of ethnically-based federal structure as most suited to Nepal. The models cited, as I recall, were Ethiopia and the wartorn Afghanistan where the loya jirgha, the parliament of the ethnic chiefs, had a powerful role. All in all, I think it is invalid to regard federalism as the only or even the main indicator of democracy.

From still another point of view, the principle of subsidiarity - that legitimate political and managerial power should be devolved or decentralized to that unit or level that is closest to the people and the most capable to successfully perform a cluster of responsibilities, provides a valid platform to answer the question on options federal or otherwise.

On the other hand, various states in the history of Nepal have long promoted a Hills-dominant political-cultural structure and ethos. The structure and ethos often favored the Hills "high caste" - and landed - groups. Sometime later, however, it was mainly the urban dwelling high caste households that wielded power. There remains a considerable continuity of political-cultural inequality and discrimination even now. Such inequality does not sit pretty, in particular, in a republic and a democracy, where citizenship is defined in terms not only of legal but also political-cultural equality. That is why the call for a federal re-structuring hit a raw nerve particularly in the Madhesh-Tarai region during decade of political turmoil and brittleness during 1996-2005.

It is politically unwise to dismantle the mandate of federalism that Nepal has today. It is necessary instead to strengthen cooperative and inclusive federalism that, to a substantial extent, mandates a collaboration among the federal, provincial and municipal levels. Successes in such collaboration can potentially go some way in healing the inequality and rift among the federal level and the provinces and municipalities as also among ethnic regions and peoples. In addition, successes on the front of federalism may also lead to interprovincial and interregional collaboration on a number of other fronts. The federal structure in Nepal today may also rationalize investment and production opportunities as well as the popular ownership of the political system that remains under evolution.

On the other hand, the nature of federalism posited by the Maoists would have strayed far from national interests. It would have enhanced centrifugal features to such an extent that internal and external interests would have likely coalesced to further weaken the country. It would also have severely harmed the cycle of economic and cultural exchange among units within the federation. Maoist design of "ethnified" states was predicated, first, on the largely discredited essentialist and ahistorical version of ethnic identity. Two, it was also predicated, a la the Soviet Union, that the Maoist one-party rule will, while allowing a cultural space to ethnicity, annul or sharply dilute the ethnic identity of all provincial leaders. The Maoist presumption was that all political leaders, regardless of their ethnic identity, would be the members of a single communist party. To boot, the more radical Maoist formulations carried federalism to other extremes, e.g. a massive geographical shift of specific social categories of population, i.e. specific caste and ethnic groups, to specific provinces and enclaves, political change such that all citizens are required to claim provincial citizenship rights, and so on.

Modern nation-states came into being from the ashes of very small-scale social units and ethnic enclaves. This transition has paid off in many ways, e.g. a more cosmopolitan culture, increase in mutual respect, and reduction both in relative seclusion, mistrust and animosity, a larger market for production, labor, goods and services as well as a larger source for generation of government revenue, etc. Going back to an "ethnified" state risks all of these gains.

As implied, the Maoist variety of federalism, of course, was not one that I could support. I also believe that the popular image of federalism, for quite some years, was sullied precisely because of such formulations by an armed 
and politically powerful political party. While the federal structure as it exists today is still under some cloud, going back to a unitary state now is impossible.

Even as the federalist and inclusionary agendas are often treated separately, it is important to couple them together. Both the agendas are geared to widen and deepen democracy. In particular, if we can visualize an inclusionary agenda as one that is anti-caste, the significance of the agenda in Nepal today is multiplied by several folds. I am afraid this agenda is not being pursued with any seriousness.

Question 7: Sociological texts and newly published materials are important resources for students pursuing an MA or MPhil in sociology. Which books and resource would you recommend them for enriching their sociological knowledge and to inspire new ideas to spark advancement in the field?

This is a difficult question to answer. There are many good texts. We should surely make an effort to choose from among the many good texts that identify seminal ideas, elaborate and link them up with the life of students. The English language, in which most such texts come to us, does present an additional problem for many students (as well as some teachers). But I have been partial to the idea that unlike at the undergraduate level, graduate students must earn proficiency in the English language.

I shall come back to the issue of texts later. If I understand you fully, however, and going beyond texts, much of the problem of learning, teaching and academic management of our universities, I think, lies elsewhere. Barring exceptions, we miss the qualities of engagement and professionalism by a long distance. By "we," I mean all of us - the teacher, administrators and students. Barring exceptions, teachers are there at the university not for making certain that the students learn but for the cultural value of being in an employed state and for the economic value of monthly paychecks. The administrators are there not to solve problems and compete with other universities but to see that the boat is not rocked much. The students are there in order not to learn but to acquire a certificate. On the otther hand for teaching-learning to improve substantially, this rut must be cleared. Texts, good and notso-good, do play a role. But, in the situation we are in, texts as such do not play the primary role.

Barring exceptions once again, much of the blame for this lies with respective actors, the teachers, administrators and students. At one level, the problem is so baffling to me: Why are so many teachers, administrators and students almost wasting out their lives out of sheer self-volition? Why are not they, foremost, engaged and enjoying positions and roles that they chose themselves? Is it unworthy to teach, manage and learn well? Is it enjoyable instead to become a teacher that most students do not respect? Or an administrator who is widely regarded as unprofessional or minimally professional? Can a student be happy knowing that he or she has not really learned through two - or four - years of the university? At another level, of course, there is not much to be baffled at. When mediocrity and lack of professionalism become normalized - "that is what everyone else does" - it requires an outlier to rise up. I am personally not, in exclaiming all this, above the water. I know I could have done better, perhaps much better. I do not wish to lay all or most blame on the "system" either. While I am not the sole agent and even as the system did shape what I have been able or unable to do, there must be a large measure of agency in my failures.

I would be amiss if I did not note that there are professionals among us who have risen up. The level of professionalism among most teachers, administrators and students would have been worse were it not for them.

It is important to go back once again to the question as you put it, however. Many if not most students attach a foreignness to the texts and do not seek to engage with, internalize and critique them. Of the underlying causes, three are immediately important. One, as noted, most texts are in English and many students are weak in the language. Two, most students do not prioritize learning but seek to acquire a diploma. Many if not most teachers do not or are unable to "translate" and transpose the texts to the lives of the students and the society they inhabit. In consequence, the level of engagement of students with the texts remains tenuous at best. I believe this is the problem that must be resolved first. Repairing other damages will become easier once we are able to engage the students with the texts.

Finally, both in teaching and research, I have consistently attempted to show that it is important to learn from metatheories as well as substantive theories and to utilize such learning in preparing a research framework. I have tried to show that descriptive categories are themselves rooted in implicit or explicit metatheory and theory. Amidst the general rush among teachers and students to collect field data, I - in consort with several colleagues - have frequently requested them to adequately re-view literature and define research problems concretely while at the same time linking the problems to more general theoretical knowledge. I have often reminded students that much of the field lies inside the head of a researcher. This was, of course, the message both of the German critical theory, which is also known as the "Positivist Dispute" that began in the 1920s and was carried through in the latter half of the last century by Theodor Adorno and Jurgen Habermas. It is also the message of the maxim that I quoted earlier, "we do not see the world as it is but as we are".

Question 8: The curriculum of sociology in Tribhuvan University has been revised through the years. You have been actively engaged in this process. What are the strengths and weaknesses of the curriculum?

I have certainly been engaged over the years in preparing the courses of studies in Sociology in company with several other colleagues. In terms of courses as such, 
I think we are doing quite well. However, there are two major shortfalls. The first is the relative paucity of texts on Nepali society. Second, and at the undergraduate level, there is a relative lack of texts in the Nepali language. These are serious shortfalls. I hope these shortfalls can be addressed during the next round of course preparation based, in part, on intense exchange with the teachers who actually teach specific courses.

On the other hand, in my heart, I have always been uncertain if I can take any credit for the preparation of courses. If I can, I also realize that there is a huge concurrent burden that I must shoulder. I firmly believe that each teacher should frame the course he or she wishes to teach. That is one of the inalienable responsibilities of a teacher. This is, however, not what happens at the Tribhuvan University, my workplace. So, there is a massive contradiction between what I just said and what I have actually been doing for long years. I do not at all feel good about it.

$\mathrm{TU}$ is a massive university - one of the largest in the world. It has 60 constituent and 1080 affiliated campuses scattered across the country. Sociology is a popular subject and is taught in approximately 350 campuses. Like in the case of other disciplines, there is a Sociology Subject Committee in the university. I have been a member of the committee for all of the four decades I have been here. This committee draws up all the courses for the undergraduate, Master, MPhil and PhD levels. On the other hand, the mandate of the committee is mostly undefined. The committee also remains largely moribund. The full committee meets rarely; only a smaller "standing committee," meets intermittently during some of years. During some of the years, the committee has not meet at all. Often, it does not possess the clout to enforce its decisions. More importantly, perhaps, as befits a centralized course preparation and decentralized course implementation system, there should have been an active information sharing system under which one component is aware of the experience of the other. Unfortunately, such an exchange of information is rare here. Most importantly, the centralized course preparation system constitutes an abdication of intellectual responsibility as well as an intellectual surrender on the part of most the teachers of the university. Those who prepare courses under this system, including I, are overbearing creatures who do not let others play their legitimate intellectual role as well as the possibilities of their intellectual growth and autonomy. But both set of actors are ceaselessly prodded at it by a system that is archaic, unfulfilling and unproductive. It also contributes to the intellectual and professional retardation of most of the teachers of the university. This condition of intellectual dependence is completely inimical to the production of new knowledge. It, in addition, seriously detracts from an appropriate pedagogical environment.

\section{Question 9: Social sciences are least preferred subjects}

in Nepal. Political leaders and bureaucrats rarely acknowledge the importance of social sciences. What do you think about the future of social science in general and sociology in particular?

Indeed, social sciences are not valued, are they? Certainly, the best-performing students, students from urban households, those from the middle and upper classes, in general, prefer it the least. "Preference," however, is not merely an individual disposition. As sociologists, we know that individual volition is socially shaped.

We do not know if social science graduates fare better or worse in life. However, it is the case that there is much parental pressure over students - and a wider social pressure over parents and guardians - to move into fields other than social sciences and the humanities. The main fear regarding social science is that the graduates will remain unemployed for quite some time following graduation and that employment, if accessed, will likely be temporary. There is also some fear that the income of social science graduates will be lower than that of others. Parents also worry that their children will not possess marketable skills; nor will they be able to become self-employed. Importantly, there is a pervading sense that everyone is automatically equipped with social science knowledge. So, why attend a university for four long years - and more if you pursue graduate studies - to acquire something that is already known or at least knowable without spending several long years there?

I cannot, given the substandard level of education provided in social sciences - together with the depressed job and salary market in Nepal, fault parents on these grounds. On the other hand, I also have little doubt that we can do much better with the outcome that both students and parents can assure themselves that social science is no hindrance whatsoever to the prospects of employment and income. Social science, with high quality students and teachers as well as appropriate pedagogical frames can provide students with a range of perspectives, substantive knowledge, will for lifelong learning, and quantitative, verbal and oral communication skills that can be, in general, better than that of students in the physical and life sciences as well as the applied sciences.

For all this to happen, we must become ready ourselves. As you imply, for us to become ready, there must also be a readiness to change the framework of the university on the part of those who run and control it. On the other hand, I am not all that optimistic here. That saddens me. Not the least because I confront my futility there.

That said, I do not at all discourage those who wish to commit themselves to social sciences. But they must possess a powerful will to excel. I have spoken of a few social scientists who have had those qualities. They can be found within and outside the university structure. They are just a few of them available now. But that should be enough for those who are committed, come what may, to further prise open a door that is marginally open. 
Question 10: You have been supporting the editorial team of this journal. What additional areas do you think should we focus upon and how shall we raise the quality and visibility of the journal as well as the papers published?

This now remains an important question. On the other hand, for one, you guys are far more knowledgeable on this than I. I have been friends with some of you on the team and I am a reader and well-wisher. That is about it. For another, I think, given the circumstances, the journal is doing very well. The team must be congratulated on this account. I hardly need to repeat that this is one of just a handful of journals on social science that is refereed and regular - the two hallmarks of a good journal. And you form a dedicated team. You have a sizable and regular readership. In addition, it is difficult for me to answer the question also because I am not sufficiently aware of the path you are taking now to reach your potential authors and readers.

So, my answer must be both brief and tentative, of the "maybe" form. And please mark that a "maybe" also implies "maybe not"! It is in this spirit that I offer the suggestion that it may be time to gradually venture beyond the journal's current niche in terms of the nature and quantity of both readers as well as contributors. An extension of niche can take place in either of two or both ways: extending beyond Nepal and beyond Sociology and Anthropology. Nepal will surely remain the spatial anchor of the journal but making forays (a) into other, i.e. political, economic, geographical, etc., spaces and (b) more encompassing theoretical space will change the nature and number of readers as well as contributors. I can already see some evidence of this if I compare the earlier volumes of this journal with the later ones.

Similarly, even as Sociology and Anthropology will continue to remain the disciplinary core of this journal, it may be prudent to gradually extend editorial interest to encompass the social sciences as a whole. In fact, I can also see some evidence of this in the more recent volumes of this journal. If I have fathomed well and if these are trends consciously adopted by the journal, I would consider that highly salutary. Finally, it may be prudent to begin to discuss the desirability and feasibility of also publishing monographs that are more full-bodied and detailed than articles.

Madhusudan Subedi https://orcid.org/0000-0001-64950601 is Professor and Chairperson of the Department of Community Health Sciences and Co-ordinator of the School of Public Health, Patan Academy of Health Sciences, Nepal. Email: madhusudansubedi@gmail.com

Man Bahadur Khattri, https://orcid.org/0000-00024291-7920 holds Ph. D. from Tribhuvan University, Kathmandu, Nepal and M. Phil. from University of Bergen Norway. Currently, Dr. Khattri is Associate Professor in anthropology at the Central Department of Anthropology, Tribhuvan University, Nepal. He is serving as founding Editor and Editor-in-Chief of the Dhaulagiri Journal of Sociology and Anthropology.

Email:mankhattri@gmail.com, man.khattri@cda.tu.edu. np 